\title{
Koverte handelingsdimensies: 'n Kritiese fokuspunt in die opleiding van aspirant-opleiers
}

\author{
Hugo G. van Rooyen \\ Departement Didaktiese Wetenskappe, Randse Afrikaanse Universiteit, Posbus 524, Johannesburg 2000 \\ Republiek van Suid-Afrika
}

\begin{abstract}
Covert performance dimensfons: a critical focal point in the tralning of trainers. The teaching competence of a trainer is to a large extent determined by his covert faculties. Teaching theories and models, as well as training programmes for trainers, which do not place sufficient focus on the covert performance domain are guilty of a too narrow interpretation of the essence of the teaching act. The complex nature of the covert performance domain and the important influence that the different facets thereof exert on the trainer's teaching competence are dealt with in depth. The main implications for training of trainers are indicated.
\end{abstract}

\begin{abstract}
Die opleier se koverte kwaliteite bepaal in 'n hoè mate sy algemene opleidingskundige vaardigheid. Opleidingsteorię en -modelle, asook opleidingsprogramme vir aspirant-opleiers, waarin die koverte handelingsdomein van die opleier nie prominent figureer nie, maak sigself skuldig aan 'n ernstig verskraalde visie van die handelingsgebeure in onderrigleersituasies. In hierdie artikel word die komplekse aard van die koverte handelingsdimensies in onderrigleersituasies en die noodsaakheid daarvan as fokuspunt in die opleiding van aspirant-opleiers van nader beskou. Enkele belangrike riglyne vir opleidingsprogramme word aangetoon.
\end{abstract}

\section{Inlelding}

Die handelinge van opleiers bevat beide overte (sigbare) en koverte (onsigbare) dimensies. Shavelson sê met reg:

'Any teaching act is the result of a decision - sometimes conscious but more often not - that the teacher makes after the complex cognitive processing of available information' (1973: 144).

Synde die enigste vorm van stimulus wat die leerder in die opleidingsituasie kan waameem en waarop hy kan reageer, vorm die overte gedrag van die opleier ongetwyfeld 'n belangrike faset van, en grondslag vir, die interakticwe onderigleergebeure. Die beste opleidingskundige insigte, intensies, ordeel en besluitneming kan egter verongeluk word indien die overt-vormlike waarin dit geoperasionaliseerd tot uiting moet kom, kwalitatief swak, onvanpas of gewoon ondoelmatig is.

'... it is obvious that what teachers do is directed in no small measure by what they think... To the extent that observed or intended behaviour is "thoughtless", it makes no use of the human teacher's most unique attributes. In so doing, it becomes mechanical and might well be done by a machine' (National Institute of Education, aangehaal deur Shavelson \& Stern, 1981: 457).

Uit die literatuur oor didaktiese handelinge is dit duidelik dat die koverte handelingsdomein tot betreklik onlangs relatief min aandag geniet het, terwyl die overte domein, daarenteen, reeds relatief omvattend en intensief omskryf is veral deur navorsers binne die interaksie-analise denkskool. Dit is maar eers relatief onlangs dat navorsers hulle ernstig op die koverte handelingsaspekte van opleiergedrag begin toespits het (vergelyk Yelon \& Desmedt, 1988; Zahorik, 1981).

In hierdie artikel word die aard van die koverte handelingsdimensies in onderrigleersituasies, en die noodsaaklikheid daarvan as fokuspunt in die opleiding van aspirantopleiers, van nader beskou. Daarmee word egter nie die belangrikheid van die ander erkende handelingsdomeine, naamlik die affektiewe en psigomotoriese, in die gedrag van 'n opleier misken nie.
Vir die doel van hierdie artikel word die aanname gemaak dat opleiding, na sy grondliggende essensies, dieselfde wesenseienskappe as onderwys vertoon. Beide verskynsels is in wese onderrigleergebeure. As sodanig vertoon beide noodwendig bepaalde gemeenskaplike wesenstrekke wat dit grootliks eenderssoortig (maar uiteraard nie identies nie) maak en meebring dat die argumente betreffende handelingsessensies van die onderriggewer waarop in hierdie artikel gefokus word, tot 'n baie groot mate ewe geldig is vir opleidingsituasies as vir ander onderwyssituasies. Byvoorbeeld: 'n Vooraf situasie-analise, doelwitbepaling, seleksie en ordening van bepaalde leerinhoude wat ontsluit moet word, bepaling van strategiez en modi vir die ontsluiting van die inhoud aan die leerders, asook besinning oor moontlike evalueringsmetodes, is aksies wat enige onderrigleersituasie vooraf behoort te gaan. Dit geld ongeag of die persoon wat gaan onderrig ' $n$ onderwyser in die skool, ' $n$ dosent aan ' $n$ universiteit of ' $n$ opleier van opleiers in die bedryf is, en ongeag of die leerders skoliere, universiteitstudente of aspirant-opleiers is. Gedagtig aan die fokus van hierdie artikel is dit veral belangrik om te noem dat die interaksies tussen onderriggewer en leerder, en meer bepaald die onderrighandelinge van die onderriggewer (soos dit in dié artikel onder die loep kom), soortgelyk is in die onderskeie bogenoemde onderrigleersituasies.

Verder toon ook die soort onderrigkwaliteite ('instructional competencies') wat Maddocks \& Yelon (1986) vir opleiers identifiseer, 'n sterk ooreenkoms met dié wat vir onderwysers sou geld. Ook dít bevestig die eenderssoortigheid van onderwys en opleiding.

Die bestaan van fyner nuanseverskille tussen die opleidings- en onderwyspraktyke wat voortspruit uit veral kontekstuele verskille tussen die verskillende onderrigleersituasies en -omgewings, word egter nie oncken nie. Hier word veral gedink aan faktore soos die eiesoortige eise wat die volwasse leerder in opleidingsituasies meebring (Peterson, 1988: 49), die aard van die leerinhoud, die onderrig- en leertempo, die potensiaal vir selfstandige 
studie, ensomeer. Verderaan word meer breedvoerig ingegaan op die rol van kontekstuele variante in die onderrigleergebeure.

Vir die fokus van hierdie artikel lyk die aanname dat onderwys en opleiding eenderssoortige gebeure is, dus geregverdig.

\section{Aard van die koverte handelingsdomein}

Volgens Lowyck (1979b) is die belangrikste elemente van die koverte dimensie van vaardige opleiergedrag die volgende:

- die vermoe om 'n situasie effektief te analiseer ten einde daarin die kritiese relevante faktore, waarvolgens en waarmee gehandel moet word, te identifiseer;

- die vermox tot antisipering van leerdergedrag, asook die gevolge van spesifieke opleierhandelinge;

- verantwoordbare en deskundige besluitnemingsvermoe betreffende gepaste handelinge om te implementeer;

- effektiewe regulering van die tempo van interaksieepisodes;

- effektiewe uitvoering van die vereiste overte handelinge (wat voortdurende, doelgerigte koverte kontrole en verifiëring van die uitvoering van die betrokke overte handelinge insluit); en

- deskundige en effektiewe interpretasie van die terugvoerinligting.

Die belangrikheid van hierdie kem-elemente van die koverte domein word ook sterk bevestig in navorsing oor die besluitneming- en beplanningsaktiwiteite van onderriggewers (vergelyk Yelon \& Desmedt, 1988; Shavelson \& Stem, 1983).

Morine-Dershimer (1988) se siening van die konsep 'practical arguments' in onderwysergedrag, werp verdere lig op die aard van die koverte handelingsdomein (vergelyk ok Green, 1976). 'Practical arguments' dui op 'n besluitnemingstrategie wat op of 'n handeling self of 'n intensie om op ' $n$ bepaalde wyse te handel, uitloop. Dit berus op minstens een van drie moontlike tipes vooronderstellings ('premises'), naamlik:

(a) situasionele vooronderstellings wat die opleier se persepsic van die situasionele konteks van die onderrigleergebcure bepaal;

(b) empiriese vooronderstellings wat die 'as..., dan...'-tipe oorwegings van 'n opleier in onderrigleersituasies behels;

(c) waarde-vooronderstellings wat op die opleier se siening van die verlangde toestande en/of gewenste verloop of uitkomstes van onderrigleersituasies dui.

Hierdie vooronderstellings is ' $n$ inherente deel van die opleier se persoonlike opleidingsfilosofie (vergelyk die deel oor beroepsfilosofie), wat uiteindelik die handelinge van die opleier grootliks bepaal. As sodanig bevestig dit die sterk interafhanlike relasionaliteit tussen die persoonlike beroepsfilosofie, koverte handelingsdomein en overte gedrag van 'n opleier.

Ter illustrasie van die akwaliteit van die opleier se koverte aktiwiteite in die onderrigleersituasie in die algemeen, kan enkele voorbeelde uit hierdie handelingsdomein aange-
dui word.
Daar word algemeen aanvaar dat 'n opleier soepelheid moet demonstreer betreffende die uitvoering van 'n be. plande reeks opleidingsaktiwiteite en die implementering van bepaalde opleidingsaktiwiteite (Sprinthall, Whiteley \& Mosher, 1966). Vir Gage is die kunselement van onderwysgee juis in hierdie soepelheid gelex:

'No one can ever prescribe successfully all the twists and turns to be taken as the lecturer, the discussion leader, or the classroom teacher uses judgement, sudden insight, sensitivity, and agility to promote leam. ing' (1979: 15).

Faktore soos byvoorbeeld die tyddruk wat dikwels in onderrigleersituasies geld, bring mee dat 'n opleier by uitstek vaardig moet wees in byvoorbeeld die vermoe om te kan herbeplan en improviseer (dikwels binne sekondes) wanneer die onderrigleergebeure sou afwyk van sy beplande verloop. Klaarblyklik is onderrigsoepelheid in hierdie konteks dan onder meer 'n direkte funksie van die kwaliteit van die kognitiewe prosesse (koverte handelinge) onderliggend aan die herbeplanningaksies van die opleier. Onderrigsoepelheid behels dus veel meer as die blote (overte) vaardigheid in 'n verskeidenheid van onderrigstrategiex, -modi en'-tegnieke (vergelyk ook Grell, 1976: 109 e.v.). Vir die opleiding van opleiers is hierdie 'n uiters belangrike aspek. om in gedagte te hou. Morrison is heeltemal reg wanneer hy sê dat

'...the deployment and evaluation of teaching acts lack significance if one knows little about the cognitive plans and affective impulses which initiate their use and which produce creative modifications in the experiences of teachers and pupils' (1977: 215).

Davis \& Roper sluit hierby aan wanneer hulle opmerk: 'The best practice of teaching involves being able to develop practical thinking and practice in response to changes in the reality of the teaching situation in a continuous immediate interaction' (1982: 151).

Sekere opleidingsmodi, byvoorbeeld dosering en demonstrasie, behels 'n laer frekwensie van interaksie tussen opleier en leerders as ander modi, byvoorbeeld gesprek en begeleide selfontdekking. Logieserwys hou 'n hoerr frekwensie van interaktiwiteit in 'n les vir die opleier die potensiaal in vir meer gedwonge afwykings van sy lesbeplanning, en daarmee saam dus 'n hoèr mate van koverte aktiwiteit. Vir 'n opleier, wat nie werklik vaardig en selfversekerd op die koverte handelingsterrein is nie, kan die neiging dus uiteraard groot wees om, hetsy bewustelik of onbewustelik, voorkeur te gee aan opleidingstrategiex en -modi wat die minimum eise aan sy koverte vermoéns stel (soos byvoorbeeld blote dosering). Die wesentlike gevaar bestaan klaarblyklik dat dit tot die uiteindelike vestiging van sodanige permanente opleidingstyl by so 'n opleier sou kon lei.

Navorsing wys egter daarop dat 'n opleier se voorafbeplande onderrighandelinge vir ' $n$ les in 'n hoe mate as ' $n$ betreklik rigiede denkraamwerk en -rigsnoer vir die uitvoering van die interaktiewe handelinge tydens die lesverloop dien (vergelyk MacLeod \& McIntyre, 1977: 118 e.v.). Dit is gewoon onrealisties om te verwag dat die opleier se kognitiewe inligtingverwerking elke moontlike gebeure in die normale snelverlopende gang van 'n onderrigleersituasie volledig en in detail kan hanteer, ten einde 
tot 'n handelingsbesluit te kom. Daarom verloop die operasionele funksionering van die koverte handelingsdimensie vermoedelik in terme van breèr, meer algemene besluitnemingstrategiee eerder as 'n menigte diskrete besluitnemingsaksies. Verder is ook bevind dat interaktiewe onderwyserhandelinge dermate deur onderwysers geroetineer word (waarskynlik omdat dit die druk van bewustelike inligtingverwerking en besluitneming verminder), en dat daar nie maklik daarvan afgewyk word nie (Yinger, 1979; Shavelston \& Stern, 1981: 482). Dié verskynsel as sodanig is nie noodwendig negatief nie. Indien hierdie roetines egter neerkom op onverantwoorde, insiglose gedragspatrone wat 'konteksblind' is, sou dit op 'n emstige leemte dui betreffende die opleier se koverte sensitiwiteit en vermoěns en soepelheid tydens die lesverloop.

Tweedens neem alle verantwoordbare remediërende begeleidingsaksies van die opleier hul vertrek vanuit 'n aanvanklike identifisering en diagnose van die betrokke probleem wat die leerder ervaar. As sodanig vereis dit van die opleier 'n sterk element van kognitiewe aktiwiteite soos diskriminerende persepsie, betekenistoekenning en analise alvorens hy 'n besluit kan neem (op sigself 'n koverte aksie) oor welke begeleidingsaksies om te implementeer (vergelyk Lowyck, 1979a). Tydens die verloop van die begeleiding dien die voortdurende kontrolerende en evaluerende aktiwiteite van die opleier as verdere voorbeelde van belangrike koverte opleierhandelinge.

Die krities-belangrike rol van die koverte dimensie in die opleier se gefundeerde professionele oordeel en besluitnemingsvaardigheid spreek duidelik uit die enkele voorafgaande voorbeelde. Dit kan onbetwisbaar as 'n basiese voorvereiste vir, en determinant van die effektiwiteit van opleidingshandelinge beskou word. Flanders som hierdie aspek treffend op wanneer hy tot dié gevolgtrekking kom:

'It is hard to imagine any aspect of teaching that is more critical to success than receiving, classifying, abstracting, storing, and then acting on the information that is inferred from pupil behaviour' (1973: 33).

Die belangrike insig wat uit die bogenoemde voorbeelde na vore tree, is dat die opleier se opleidingskundige oordeel ('n grondliggende koverte aangeleentheid) oc̈nskynlik in direkte eweredigheid tot die potensiele kwaliteit van sy onderwysgedrag staan. Krüger \& Müller (1987: 2) beweer tereg dat onderwyshandelinge 'n oordeelvereiste ten grondslag het. Fyner ontleed, omvat opleidingskundige oordeel bepaalde koverte handelingsvermoëns, soos byvoorbeeld analise van 'n situasie in terme van relevante en irrelevante aspekte; die oorweging van spesifieke aksies en die opweeg van alternatiewe teenoor mekaar; die antisipering van moontlike gevolge van spesifieke aksies; die verantwoordbare keuse van 'n geskikte aksie aan die hand van die bogenoemde vermoëns. Hierdie vermoëns moet berus op outentieke opleidingskundige insigte van die opleier self. Sonder sodanige opleidingskundige cordeel is die opleier grootliks aangewese op onverantwoordbare navolging van opleidingskundige 'resepte' en/of klakkelose nabootsing van die gedrag van ander onderriggewers.

\section{Beroepsfilosofie as 'n determinant van opleiergedrag}

Die vraag ontstaan nou wat die fundamentele determinant van die opleier se koverte gedrag is. Dit wil voorkom asof die koverte gedrag van 'n opleier in 'n hos mate beheer word deur sy partikuliere opleidingsfilosofie. Laasgenoemde is die multidimensionele produk van die interafhanklikheid tussen diepere persoonsdimensies soos, onder meer, sy persoonlike waardestruktuur, lewensopvatting en wêreldbeskouing asook intuïtiewe opleidingsteorie. 'n Individu handel immers, behalwe vanuit 'n kennisbasis, minstens óók op grond van, en ooreenkomstig sy persoonlike waarde- en normstruktuur, persepsies en dergelike elemente van die 'wees'-dimensie. Vermoedelik geskied 'n individu se persoonlike betekenisgewing en waardetoekenning aan bepaalde inligting (sy 'kennis' dus) ook grootliks vanuit genoemde 'wees'-dimensie. Dit blyk dus noodsaaklik te wees om die komplekse interafhanklike verband tussen genoemde drie dimensies te erken.

'n Opleier se beroepsfilosofie bestaan waarskynlik uit 'n kombinasie van 'n bewustelike en 'n intuïtiewe komponent (vergelyk McQualter, 1985: 181 e.v.; Vedder \& Bannink, 1988: 13/14); is oënskynlik nie-staties van aard en dus onderhewig aan veranderings van 'n tydelike of meer permanente omvang. Breedweg beskou is hierdie beroepsfilosofie die produk van veral

(a) die opleier se totale mens- en werklikheidbeskouing soos onder meer weerspieêl word in sy partikuliere lewensopvatlike en religieuse waardestrukture en stellingnames (vergelyk Combs, et. al., 1977: 99 e.v.);

(b) sy intuïtiewe waardebepaling van en vooronderstellings betreffende onderrigleer as sodanig, met inbegrip van sy rolpersepsie van 'n opleier (vergelyk Lasley, 1980). Green (1976) en Morine-Dershimer (1988) verwys hierna as 'premises in the practical arguments of teachers' (vergelyk ook Grell, 1976: 58 e.v.; Vedder \& Bannink, 1988). (In die geval van die aspirant-opleier is hierdie aspek waarskynlik reeds tydens sy skoolloopbaan in die waarneming van sy onderwysers ontwikkel - vergelyk Britzman, 1986; Book, Beyers \& Freeman, 1983); en

(c) die invloed van die opleiding wat hy ondergaan het (vergelyk Rogus \& Schuttenberg, 1979; Claxton, 1985: 91-92).

Uit die literatuur word dit duidelik dat die opleier se beroepsfilosofie wesenlik uit sy persepsies betreffende verskillende deelkomponente van die onderrigleerverskynsel bestaan (vergelyk De Jong, 1983; Shavelson \& Stem, 1981; Yaakobi \& Sharan, 1985; Grell, 1976: 58 e.v.). In hierdie verband kan die volgende perseptuele domeine onderskei word:

- Leerinhoudpersepsie: Hieronder ressorteer die opleier se cortuigings en persepsies betreffende aspekte soos kennis per se; die sin- en betekenisvolheid, moeilikheidsgraad, onderrigmoontlikhede en dergelike aspekte van die kurrikulum of slegs 'n betrokke snit van die leerinhoud.

- Leerderpersepsie: Dit sal sienings oor aspekte soos byvoorbeeld die leergebeure by die leerder, motivering, individualisering, verwagtings van leerders, asook leerdergedrag en -intelligensie insluit. 
- Selfpersepsie: In hierdie domein word onder andere die opleier se selfkennis, selfbeeld en selfvertroue, vakkundighcid, belangstellings, motivering, keierskap- en bestuurstyl, opleidingsprioriteile en beroepserns geressoncer.

- Leeromgewingpersepsie: Hier gaan dit veral om oortuigings rakende sosiale en bestursaspekte soos byvoorbeeld klasgroepkuluuur en -dinamika, gesag, orde en dissipline, asook strukturering van die onderrigleersituasie en -ruimte.

- Operasionaliseringpersepsie: Die opleier se oortuigings angaande aspekte soos gewenste opleidingstrategiez, interaksiepatrone, onderwysmedia en evalueringsvorme word in hierdie domein geakkommodeer.

Dar kan vanselfsprekend nie van absolute skeidslyne tussen die bostaande perseptuele kategoriex sprake wees nie. De Jong (1983: 133) kom tot die slotsom dat 'n opleier se besluitnemings primêr op die aktiwiteite in die operasionaliseringskategorie gerig is en dat die keuse, beplanning en uitvoering daarvan van sy vooronderstellings en cortuigings in die ander vier kategoriex afhanklik is.

Met betrekking tot die wesenlike effek van die beroepsfilosofie op die handelinge van 'n opleier, moet egter onthou word dat die beroepsfilosofie per se op sy beurt weer sterk beïnvloed kan word deur sekondêre kontekstuele faktore, soos institusionele determinante (byvoorbeeld die opkeidingsbeleid, organisatoriese aspekte, kurrikulum, asook persoonlike beroepsambisies van die opleier) en kontekstwele aspekte vanuit die samelewingsfeer (byvoorbeeld die beeld van die professie, samelewingsverwagtinge van die opleidingsinstansie en sosio-politiese invloede op die opleiding).

\section{Opleidingskundige vaardigheld en die koverte han- delingsdimensies}

Die verurekpunt vir die konseptualisering van die begrip opleidingskundige vaardigheid is waarskynlik geleè in die aanvaarding van die aanwesigheid en noodwendigheid van minstens die volgende aspekte in die opleier se professionele gedrag (vergelyk Van Rooyen, 1989: Hfste. 3 \& 4):

1. 'n wetenskaplik verantwoordbare tegnies-vormlike handelingsdimensie in die opleidingstaak van die opleier,

2. 'n individualistiese, personale gedragsdimensie soos weerspicil in 'n persoonlike opleidingsfilosofie en eie opleidingstyl by opleiers;

3. die koverte dimensie as determinant van die waarneembare handelinge van die opleier,

4. 'n doelmatigheid in die handeling(e);

5. die kontekstuele afhanklikheid van vaardige opleiergedrag.

Oorbeklemtoning van enige van dié handelingsdimensies sal egter onvermydelik tot 'n eensydige en onvolledige voorstelling van vaardige opleierhandelinge lei (vergelyk Van Rooyen, 1989: 180 e.v.).

In terme van die operasionele handelingsinhoud dui opleidingsvaardigheid op 'n handelingsvermoé waarin beide 'n overte en 'n koverte dimensie, in variérende mate van dominansie, onderskei kan word. Hier vereis opleidingsvaardigheid dus die aanwesigheid van 'n hox kwaliteit van beide overte en koverte dimensies in die handelinge van 'n opleier. Opleidingsvaardigheid word dikwels hoofsaaklit op grond van overte handelinge beoordeel, maar alle vomis van vaardige opleiergedrag behoort in meerdere of mindere mate op 'n teoretiese kennisbasis te berus ('weet dat...' a 'weet hoe...' En 'weet waarom...') en is in die uitvoering daarvan op 'n deurlopende kognitiewe sturing aangewax. (vergelyk Wragg, 1984; Tomlinson \& Smith, 1985: 107). Om sowel professioneel as sinvol te wees, moet 'n opleiertandeling immers nie toevallig doeltreffend uitgevoer word nie, maar moet dit herhaalbaar en op 'n kwalintie hox vlak uitgevoer kan word en selfs verbeter kan word. Dit bevestig die rasionele grondslag as kriterium vir hando lingsvaardigheid. Daarmee word die opleier se inligtingsverwerkings-, besluitnemings- en refleksievermoèns an -meganismes by implikasie as grondliggende komponente van opleidingsvaardigheid bevestig - handelingselemente wat veral ook deur die kontekstuele afhanklikheid van opleierhandelinge genoodsaak word (vergelyk Yelon \& Desmedt, 1988; Van Rooyen, 1989: 207/208).

'The more complex and variable the educational environment is seen as being. the more one must rely on teacher judgement or even insight to guide the activi-

: ties of classroom life, and the less one relies on generalized rules for teacher behaviour' aldus Darling-Hammond, et al. (1983: 297).

Handelingsvaardigheid moet dus nie as meganistiese, insiglose handelingsroetines gesien word nie - die betekenisvolheid van 'n vaardigheid is veral grootliks van die wendbaarheid daarvan (d.i. toepassing in varierende vorme in wisselende situasies) afhanklik (Van Parreren, 1983: 85). By die uitvoering van 'n betrokke vaardigheid noodsaak juis dit die opleier se insig in die onderliggende (teoretiese) rasionaal vir die aanwending daarvan. Shavelson sê tereg:

'What distinguishes the exceptional teacher from his colleagues is not the ability to ask, say a higher-order question, but the ability to decide when to ask such a question' (1973: 144)

en Allen \& Ryan gaan akkoord dat

'...teaching is not a series of happenstances, but a series of professional decisions' (1969: 23) (vergelyt ook Lowyck, 1979b).

Sekere vaardighede kan vermoedelik minstens dermate geinternaliseer word dat dit in outomatisme oorgaan, in welke geval die bewustelike kognitiewe sturing daarvan gaandeweg tot 'n minimum afgeskaal word.

\section{Koverte dimensies in die opleiding van aspirant- opleiers}

Dit is duidelik dat die koverte handelingsdomein 'n tritiese komponent van die operasionele handelingsinhoud verteenwoordig. Die koverte gebeure dien enersyds as knooppunt tussen die opleier se teoretiese insigte (die ken-dimensie), sy persoonlikheid en beroepsfilosofie (die wees-dimensie), en sy overte gedrag (die kan-dimensie); as die knooppunt tussen teorie en praktyk. Andersyds dien dit as knooppunt tussen die genoemde aspekte aan die een kant en die magdom komplekse, situasionele konteksvariante aan die ander kant. As sodanig vorm dit die hart van potensieel professionele opleiergedrag en verteenwoordig dit 'n krities belangrike aspek in die opleiding van aspirant-opleiers. 
Omdat opleiers egter onmoontlik voorberei en opgelei kan word vir elke moontlike kontekstuele variant wat in die onderrigleersituasie mag opduik, noodsaak dit optimale wendbaarheid van hul opleidingsvaardigheid. Dit kan alleenlik geskied op grond van rasionele insig in wát hy doen en wáárom hy dit doen. Opleiers moet in staat wees om hul professioncle kennisbasis op kreatiewe wyse te operasionaliseer, om dit aan te wend as grondslag vir hul opleidingskundige interpretasie van situasies, opleidingskundige oordeel en -besluitneming met betrekking tot al hul onderskeie taakdimensies. Hierdie soort gebeure sentreer in die koverte handelingsdomein. Dit impliseer dat die opleiding van aspirant-opleiers veral eksplisiet moet fokus op die student se koverte funksies in terme van aspekte soos analise en evaluering van onderrigleersituasies, sy beplanning- en besluitnemingstrategiee en die rasionaal onderliggend daaraan, asook improvisasie en opleidingskundige oordeel. Zahorik, sê tereg dat:

' $(t)$ he goal of the education of teachers must be to help teachers become increasingly more skillful and thoughtful in their work' (1986: 24).

\section{Reflektiewe opleiergedrag as doelterrein in opleidings- programme}

'n Sentrale doelstelling vir opleiding van aspirant-opleiers behoort te wees om verantwoorde en weldeurdagte opleierhandelinge te laat realiseer. Dit behoort gerig te wees op die totstandbrenging, by die student (aspirant-opleier), van handelingsvermoèns en oortuigings wat op intelligente (ingeligte, teoreties-gefundeerde) oordeel berus. So gesien, is kritiese selfrefleksie ' $n$ noodwendigheid in die mondering van 'n outonome professionele opleier (vergelyk Van Rooyen, 1989: 182-185; Vedder \& Bannink, 1988: 12-13). Refleksie word deur Zeichner \& Liston omskyf as:

'(it) entails the active, persistent, and careful consideration of any belief or supposed form of knowledge in light of the grounds that support it and the consequences to which it leads' (1987: 24$)$.

Dit kan uit 'n handelingsperspektief beskou word as die opleier se objektief-kritiese, intro- en retrospektiewe denke oor en analise van 'n afgelope onderrigleerepisode in terme van wát daarin plaasgevind het, wárom dit plaasgevind het en moontlike alternatiewe optredes wat die verloop van die episode dalk meer sinvol en doelmatig sou kon maak. Die refleksie het op beide die overte en koverte handelinge van die opleier betrekking. Hier is die belangrikste vrae wat die opleiding moet rig, die volgende: In welke mate het die student die vermoè om opleiergedrag (sy eie óf dié van ander) in gegewe situasies, op 'n objektief-kritiese wyse en verantwoord aan grondige teoretiese beginsels, te analiseer, evalueer en moontlike alternatiewe handelingswyses daar te stel? Wat is die kwaliteit van die refleksie, dit wil sê, in watter mate is die student in staat om in sodanige refleksie tot die diepere vlakke van die onderliggende koverte funksionering, opleidingsfilosofie, lewensopvatlike en waardeen normstrukture van 'n opleier deur te dring?

Die praktiese aspekte in die opleidingsprogram behoort intellektuele ervarings vir die student te wees waarin hy aktief reflekterend besig is om sy handelinge te analiseer en te verantwoord. Dit dien as opleidingsmatige geleentheid vir die student om bepaalde beroepsverwante insigte en vaardighede na die praktyk deur te trek en in te oefen. Opleiding wat op die student se vermoe tot refleksie op en verantwoording aan teorie fokus, hou inderdaad die potensiaal in vir 'n sinvolle oorbrugging van die ou probleem van sinvolle versoening tussen teorie en praktyk in opleidingsprogramme.

Opleiding van aspirant-opleiers behoort beskou te word as 'n proses van persoonlike teorievorming deur die student (dit wil sê, uitbouing, verifiëring en verfyning van sy eie lewensopvatting, persoonlike beroepsfilosofie en koverte handelingsrasionaal) eerder as die onkritiese oomeem van bestaande teoretiese besegginge. Daarmee saam behoort die student die geleentheid te kry om, onder kundige begeleiding, die insig wat langs hierdie weg bereik word, doelmatig in praktiese handeling om te sit.

Omvattende reflekterende blootstelling aan praktyksituasies sou vermoedelik tydens opleiding kon bydra tot die vestiging van belangrike professionele vermoens en eienskappe by die aspirant-opleier, onder meer 'n realistiese beskouing van praktyksituasies en -eise, 'n beter vermox tot objektiewe self-analise in professionele verband, 'n hoêr mate van wendbaarheid van sy handelingsvaardigheid, groter soepelheid in beide overte en koverte handelinge, 'n groter mate van selfvertroue by diensbetreding en 'n beter 'geskoolde intuïsie' ten opsigte van onderrigleersituasies.

Betreffende die inhoudelike van die opleidingsprogram: Ten einde die persoonlike opleidingsfilosofie en uiteindelik die koverte besluitnemingsdimensie van opleiergedrag te beïnvloed, is dit belangrik dat die opleidingsteorie vir die student (aspirant-opleier) relevant moet wees ten opsigte van die praktyk waarheen hy op pad is (Macklin, 1981). Slegs in die mate waarin daarin geslaag kan word om so 'n teorie direk tot die praktyk van sinvolle opleiding en die opleier se persoonlike praktykbeskouing en -stigting te laat spreek, kan 'n verskuiwing van die teorie vanaf potensiele betekenis na funksionele betekenis bewerkstellig word. 'n Opleidingskurrikulum waarin nie voorsiening gemaak word vir die teorie onderliggend aan praktykverwante aspekte soos byvoorbeeld situasie-ontleding, besluitneming en probleemoplossingstrategieè nie, kan gewoon nie voldoende op die praktykeise ingestel wees nie. 'n Opleidingsparadigma waarin die koverte handelingsdimensies sentraal staan, vra dus dat daar gestreef behoort te word na 'n funksionele en praktykgerigte teorie waarin op 'n kritiese wyse met beide die teoretiese en die taktiese aspekte van die onderrigleerverskynsel omgegaan word; na 'n opleidingspraktyk waarin die student (aspirant-opleier) die geleentheid het om, binne die parameters van verantwoordbare teoretiese opleidingskundige beginsels en onder begeleiding van kundige opleierdosente, sy eie praxis volgens sy eie persoonlikheid en styl te ontwikkel.

In 'n opleidingsprogram waar die student se koverte handelingsdimensies die fokuspunt is, is die kundige begeleiding wat van die opleierdosent uitgaan, na aard en vorm 'n baie belangrike aspek. Die uitdaging lê daarin om wel ingrepe op die student se koverte funksionering te doen en hom steeds genoeg ruimte te laat vir eie inisiatief en kreatiwiteit. Om een voorbeeld te noem: Om die grondliggende beginsels by die aanleer van handelingsvaardigheid, naamlik direkte terugvoering en in-aksie-begeleiding van die 
sudent tydens prakiese opleidingsessies verder te probeer optimaliseer, suggereer Smith \& Tomlinson (1984) die gebin van 'n radiomikrofoon met 'n ontvanger wat in die oor van 'n studem geplaas word tydens 'n praktiese lesaanbieding. Dil maak dil vir die opleierdosent moontlik om, ma die minimum versteuring van die onderrigleergebeure ussen die student en sy klas, doeltreffender in-aksieondersteuning. terugvoer en -begeleiding aan die student te verstaf. Langs hierdie weg kan 'n opleierdosent dus op 'n bie direkte wyse, tydens die interaktiewe gebeure, onderstenend inwert op die koverte handelinge van die student (appirant-opleier) - iets wat tot dusver nie moondlik was nie. Voorlopige bevindings mea die gebruik van hierdie opleidingstegniek blyk baie belowend te wees.

Oak uit 'n prakykgerigte opleidingsoogpunt wil dit voorkom of optimale doelmatigheid bereik kan word waar die indulctiewe benadering gekoppel word an 'n heuristiese, probleemgeoriēnteerde opleidingstrategie.

'To idencify crucial questions, rather than to seek ready made answers, seems an appropriate goal in professional training, where the essence of practice is to foster independent appraisal and judgement based on the thorough grasp of established principles', aldus De Lacey, (1983: 55).

in Bepaalde tema sou byvoorbeeld ingelei kon word met in zetcose video- of filmsnit wat 'n spesifieke beroepsverwante situnsie uitbeeld. Bepaalde aspekte daarvan kan, met die oog op kritiese analise deur die studente, as problematiek an hulle voorgehou word of omgebuig word tot probleme, byvoorbeeld die kontekstuele kompleksiteite, bestuursmarige problematiek of vakdidaktiese aspekte. Die potensiele warde van 'n probleemgeorixnteerde benadering is daarin gelex dat die koverte funksies van die aspirant-opleier, byvocrbeeld amalise, opweging van alternatiewe, besluitnemingstrategiee, en dergelike tritiese vermoêns, op direkte wyse aangespreek word. In 'n opleidingsgesprek, gebaseer op praktykgerigte toorie en/of selfontdekking deur die aspirant-opleiers, sou uikindelik by die beoogde onderliggende teoretiese beginsels uitgekom kon word.

\section{Samevatting}

Die koverte handelingsdomein, in sy komplekse interafhanklikheid ma diepere persoconsdimensies van die oplei$\boldsymbol{\sigma}$, beklee 'n sentrale posisie in die persoon se funksionering binne die komplekse handelingsituasie in die onderrigleergebeure. Die opleier se kovente kwaliteite is in 'n hoé make bepakend van sy handelingsbevoegdheid of algemene opleidingskundige vaardigheid (vergelyk Stepich 1991). Te cordoel an hierdie artikel lyk dit geregverdig om cie afteiding te matk dat onderrigleertooriez en -modelle. asook opleidingsprogramme vir opleiers, waarin die kovere handelingsdomein van die opleier nie prominen figureer nie, sigself skuldig mank an 'n enstig verskraalde visie van die handelingsgebeure in onderrigleersituasies.

'a Belangrike doelstelling vir outentieke handelingsvendigheid wa in hierdie artikel ma vore tree, het beudtaing op die sudent (aspirant-opleier) se vermos lot eflesie op sy cie oplcidingsgedrag. Die inhoud van hierdie refletwering is tweelodig: cerstens is dit gerig op die handelingsvereistes wal dit vir die student inhou (in terme van handelingstipes sowel as vereistes vir handelingsvardic. heid); en tweedens is dit gerig op die student se betekenis. en vormgewing daaraan in sy eie gedrag tydens opleiding. Enkele van die belangrike opleidingsriglyne vir 'n op. leidingspraktyk waarin die koverte handelingsdimensio sentraal staan, kan soos volg saamgevat word:

- 'n Eksplisiete fokus op, en blootstelling van die studen (aspirant-opleier) aan praktykverwante situasies, veral in terme van die handelingsimplikasies wat dit vir 'n oplejer inhou.

- Maksimum blootstelling van die student an die verskejdenheid van alternatiewe handelingswyses wal ondernifleer in verskillende situasies van die opleier verg.

- 'n Eksplisiete en daadwerklike fokus op nie slegs die overte gedragsaspekte van studente nie, maar veral ook op die koverte handelingsdomein en die persoonlike bo roepsfilosofie van studente in sowel die praktiese 8 tecretiese opleidingskomponente.

- 'n Krities-analitiese hantering van bogenoemde aspekte an die hand van 'n prakrykgerigle teorie, met 'n fakus op veral die onderskeie wesensdimensies van vaardige opleidingsgedrag. Dit impliseer 'n diepgaande analise van spesifieke praktyksitwasies in terme van die doet matigheids-, inhoudelike, tegniesvormlike, kontekswele en persoonlike eise wat dit verg.

- Stimulering van 'n kritiese self-reflekterende gesindheid en benadering tydens beide die praktiese en die teoretiese komponente van die opleidingsprogram by sudente. Hierdie kritiese selfrefleksie by die student behoort op alke vlakke van funksionering gerig te wees - vanaf die blote overte, deur die onderliggende vlakke van koverte funksionering tot die diepliggende vlakke van persoonlikheids- en karakuereienskappe, asook waarde- en normstrukture.

- In die didaktiese hantering van die opleidingsgeleenthede behoort 'n probleem-georienteerde opleidingstrategie (heuristies, induktief van aard) sentraal te staan. Sodoende moet gepoog ward on die student se koverte funksionering (analiserings-, besluitnemings- en reflekterende vermoèns asook sy opleidingskundige oordoel) optimaal in die opleidingsmatige interaksie tussen opleier en student te betrek.

\section{Summany}

In any teaching situation the competence and skill of a trainer depends to a large degree on the quality of his covent functions. The coven functioning of a trainer is closely related to his personal (largely subjective) teaching philosophy which, in turn, consists inter alia of certain premises in the mind of the trainer concerning the teaching act and -situation, as well as his personal value system and world view.

Some critical aspects related to the covert abilities of a trainer includes factors like analysis, interpretation and evaluation of a given teaching situation, sound didactic judgement, decision making, improvisation, and didactic flexibility. These abilities, as well as the oven teaching acts resulting from them, all depend on the individual's information processing skills (in itself coven actions). Therefore the covert abilities of the trainer should be central to the 
definition of the concept 'training skill' and should constitute the parameters within which the training of trainers should progress. Furthermore, the above-mentioned covertbased teaching skills culminate in the individual's ability to reflect critically and intelligently on all facets of his own teaching. Therefore, this ability should be a prime target in training programs.

To accomplish this, training programs need to put a more definitive emphasis on trainees' theoretical insight into the demands practical training situations put on all the beforementioned covert functions and skills of a trainer, as well as their ability to analyse a situation and the behaviour of trainers in terms of covert demands.

\section{Verwysings}

Allen, D.W. \& Ryan, K.A. 1969. Microteaching. Reading: Addison-Weslcy.

Book, C., Byers, J. \& Freeman, D. 1983. Student expectations and teacher education traditions with which we can and cannot live. J. Teacher Education, Vol. 34, No. 1, JanuaryFebruary: 9-13.

Britzman, D.P. 1986. Cultural myths in the making of a teacher: biography and social structure in teacher education. Harvard Educational Review, Vol. 56, No. 4: 442-456.

Claxton, G. 1985. The psychology of teaching educational psychology. In: Francis, H. (red.). Learning to teach - psychology in teacher training. Londen: The Falmer Press. pp.82-101.

Combs, A. W., Blume, R.A., Newman, A.J. \& Wass, H.L. 1977. The professional education of teachers: a humanistic approach to teacher preparation. 2nd Ed. Boston: Allyn \& Bacon, Inc.

Darling-Hammond, L., Wise, A.E. \& Pease, S.R. 1983. Teacher evaluation in the organizational context: a review of the literature. Review of Educational Research, Fall, Vol. 53, No. 3: 285-328.

Davis, D. \& Roper, W.J. 1982. Theory and practice in teacher education. European Journal of Teacher Education, Vol. 5 , No. 3: 147-156.

De Jong, J.A. 1983. Naar een handelingsgeoriënteerde opleiding. In: Fransen, H.A.M. \& Lagerweij, N.A.J. (reds.). Onderwijskunde in ontwikkeling. Culemborg: Educaboek. pp. 127-142.

De Lacey, P.R. 1983. The university experience - keystone for teacher education. In: Fielding A.J. \& Cavanagh, D.M. (eds.). Curriculum priorities in Australian higher education - an examination of curriculum issues and practices in Australian higher education with proposals for curriculum reform in teacher education. Canberra: Croom Helm Australia. pp.51-55.

Flanders, N.A. 1973. Basic teaching skills derived from a model of speaking and listening. J. Teacher Education, Vol. 24, No. 1: 24-37.

Gage, N.L. 1979. The scientific basis of the art of teaching. New York: Teachers College Press.

Green, T.F. 1976. Teacher competence as practical rationality. Educational Theory, Vol. 26: 249-262.

Grell, J. 1976. Training van onderwijsgedrag. Groningen: Wolters-Noordhoff. (Vertaal deur Riijgers, J.M.R.).

Krüger, R.A. \& Müller, E.C.C. 1987. Lesstruksuur en onderwyssukses. Johannesburg: Randse Afrikaanse Universiteit.

Lasley, T.J. 1980. Preservice teacher beliefs about teaching. $J$. Teacher Education, Vol. 31, No. 4: 38-41.
Lowyck, J. 1979a. Procesanalyse van het onderwijsgedrag. Pedagogische Studiën, Vol. 56: 427-446.

Lowyck, J. 1979b. De problematiek van de onderwijsvaardigheden. Pedagogische Studiën, Vol. 56: 109-116.

MacLeod, G. \& McIntyre, D. 1977. Towards a model for microteaching. British Journal of Teacher Education, Vol. 3, No. 4: 111-120.

Macklin, M. 1981. Teaching professionalism to the teaching profession. Australian Journal of Education, Vol. 25, No. 1: 24-35.

Maddocks, P. \& Yelon, S. 1986. Identifying trainer competencies. Performance \& Instruction, November: 9-12.

McQualter, J.W. 1985. Becoming a teacher: preservice teacher education using personal construct theory. J. Education for Teaching, Vol. 11, No. 2: 177-186.

Morine-Dershimer, G. 1988. Premises in the practical arguments of preservice teachers. Teacher \& Teacher Education, Vol. 4, No. 3: 215-229.

Morrison, A. 1977. Teachers for all seasons. British Jowrnal of Teacher Education, Vol. 3, No. 3: 212-217.

Peterson, LJ. 1988. 13 Powerful principles for training success. Performance \& Instruction, February: 47-55.

Rogus, J.F. \& Schuttenberg, E.M. 1979. The redesign of teacher education: putting the house in order. J. Teacher Education, Vol. 30, No. 5: 39-41.

Shavelson, R.J. 1973. What is the basic teaching skill? J. Teacher Education, Vol. 24, No. 2: 144-151.

Shavelson, RJ. \& Stern, P. 1981. Research on teachers' pedagogical thoughts, judgments, decisions, and behaviour. Review of Educational Research, Vol. 51, No. 4: 455-498.

Smith, R.M. \& Tomlinson, P.D. 1984. R A P: Radio-assisted practice. Preliminary investigations of a new technique in teacher education. J. Education for Teaching, Vol. 10: 119-134.

Sprinthall, N.A., Whiteley, J.M. \& Mosher, R.L. 1966. A study of teacher effectiveness. In: Hyman, R.T. (red.). Contemporary thought on teaching. Englewood Cliffs, New Jersey: PrenticeHall. pp.279-291.

Stepich, D. 1991. From novice to expert: Implications for instructional design. Performance \& Instruction, July: 13-17.

Suid-Afrikaanse Onderwysersraad. 1986. 'n Taakanalise van die onderwyser. Voorlopige verslag van 'n navorsingsprojek in samewerking met die fakulteit Opvoedkunde, Universiteit van Stellenbosch.

Tomlinson, P.D. \& Smith, R.N. 1985. Training intelligently skilled teachers. In: Francis, H. (red). Leaming to teach psychology in teacher training. Londen: The Falmer Press. pp.102-118.

Van Parreren, C.F. 1983. Leren door handelen. Appeldoorn: Uitgeverij Van Walraven bv.

Van Rooyen, H.G. 1989. ' $n$ Handelingstruktuur vir praktykgerigte onderwysersopleiding. D.Ed. proefskrif. Johannesburg: Randse Afrikaanse Universiteit.

Vedder, J. \& Bannink, P. 1988. A model of reflective teacher education in the Netherlands: a few ideas on teaching practice. European Journal of Teacher Education, Vol. 11, No. 1: 9-19.

Wragg, E.C. 1984. Teaching skills. In: Wragg, E.C. (red.). Classroom teaching skills. New York: Nichols Publishing Co. pp.1-19.

Yaakobi, D. \& Sharan, S. 1985. Teacher beliefs and practices: the discipline carries the message. J. Education for Teaching. Vol. 11, No. 2: 187-199. 
Yelon, S. \& Desmedt, J. 1988. Improving professional judgement and performance training for open job skills. Performance \& Instruction, February: 34-46.

Yinger, R. 1979. Routines in teacher planning. Theory into Practice, Vol. 17: 245-265.

Zahorik, J.A. 1981. Using insights in education. J. Teacher
Education, March-April: 10-13.

Zahorik, J.A. 1986. Acquiring teaching skills. J. Teacher Education, March-April: 21-25.

Zeichner, K.M. \& Liston, D.P. 1987. Teaching student teachers to reflect. Harvard Educational Review, Vol. 57, No. 1, February: 23-48.

\section{Errata}

Vol. 23, No. 1, 1992: p.28

The equations should read:

$P_{0}=D_{1} /(1+k)^{1}+D_{2} /(1+k)^{2}+\ldots+D_{\infty} /(1+k)^{\infty}$, where

$P_{0}=$ the value of an ordinary share today;

$D_{t}=$ the expected cash dividend per share distributed at the end of year $t$;

$k$ = the cost of ordinary shares; and

$\infty=$ infinity.

$\mathrm{D}_{1}=\mathrm{D}_{2}=\ldots=\mathrm{D}_{\infty}$,

$P_{0}=D_{0}(1+g)^{1} /(1+k)^{1}+D_{0}(1+g)^{2} /(1+k)^{2}+\ldots$ $+D_{0}(1+g)^{\infty} /(1+k)^{\infty}$,

$g^{*}=$ a constant growth rate for the period $N=1$ to $\infty$. 